\title{
Suunatud refleksiooni protseduuri rakendamise peamised kasutegurid ja kitsaskohad õpetajakoolituse üliõpilaste ja õpetajate hinnangul
}

\author{
Raili Allas ${ }^{\mathrm{a}}$, Äli Leijen ${ }^{\mathrm{a}}$, Auli Toom ${ }^{\mathrm{b}}$ \\ ${ }^{a}$ Tartu Ülikooli haridusteaduste instituut \\ ${ }^{b}$ Helsingi Ülikooli haridusteaduste instituut
}

\begin{abstract}
Annotatsioon
Tänapäeva maailm eeldab, et kõik professionaalid pööravad järjepidevalt tähelepanu oma teadmiste ja oskuste arendamisele. Hariduse valdkonnas rõhutatakse, et õpetaja pidev professionaalne areng on ühtlasi ka jätkusuutliku ja nüüdisaegse haridussüsteemi alus. Samas ei ole piisavalt uurimusi, et seletada, millised meetodid on õpetajate toetamiseks kõige sobivamad. Siinses artiklis uuritakse, kuidas tajuvad õpetajad professionaalse arengu eri etappidel suunatud refleksiooni protseduuri kasutegureid ja kitsaskohti. Uurimuses osales 21 õpetajakoolituse üliópilast ja 80 õpetajat. Uurimuses keskenduti osalejate hinnangutele, mille kohta koguti andmeid grupiarutelude ja -intervjuudega ning mida analüüsiti temaatilist analüüsi kasutades. Kokkuvõttena tuuakse välja, kuidas rakendada suunatud refleksiooni protseduuri õpetajate toetamiseks professionaalse arengu eri etappidel.
\end{abstract}

Võtmesõnad: suunatud refleksiooni protseduur, õpetaja professionaalne areng, refleksioon

\section{Sissejuhatus}

Nüüdisaja ühiskonda iseloomustavad kiired muutused, millega hakkamasaamine eeldab iga valdkonna professionaalidelt oma oskuste, teadmiste ja hoiakute järjepidevat ümberkujundamist. Sealjuures rõhutatakse, et pidevalt muutuvad olud seavad uued ootused ka praegustele ja tulevastele õpetajale neilt oodatakse, et nad aitaksid praegustel lastel kujuneda tuleviku professionaalideks, kes on võimelised kohanema ühiskonna ootuste ja vajadustega, mida ei ole veel võimalik ennustada (OECD, 2019). Seega pööratakse aina enam tähelepanu õpetajate pidevale erialasele enesetäiendamisele ja otsitakse tõenduspõhiseid meetodeid, kuidas toetada õpetajaid professionaalse arengu eri etappidel (European Commission, 2015; Feiman-Nemserv, 2001;

Haridusteaduste instituut, Tartu Ülikool, Salme 1a, 50103 Tartu; raili.allas@ut.ee. 
OECD, 2019). Samal ajal tuleb aga silmas pidada, et õpetajaskond muutub aina heterogeensemaks, mis tähendab, et õpetajad, kes vajavad toetamist, on oma ettevalmistuselt ja seega ka vajadustelt väga erinevad (OECD, 2019). Kuigi haridusteadlased on üksmeelel, et refleksioon on õpetaja professionaalse arengu lahutamatu osa (Caena, 2011), on vaja lisauurimusi, et leida meetod, mis oleks tõhus õpetajate toetamiseks professionaalse arengu eri etappidel. Siinne artikkel keskendub õpetaja professionaalse arengu toetamisele refleksiooni kaudu. Täpsemalt on artikli eesmärk kirjeldada, kuidas tajuvad õpetajad professionaalse arengu eri etappidel suunatud refleksiooni protseduuri kasutegureid ja kitsaskohti. Alljärgnevalt antakse teoreetiline ülevaade õpetaja professionaalsest arengust ja selle toetamisest refleksiooni kaudu, et luua kontekst uurimuse tulemuste tõlgendamiseks.

\section{Teoreetiline ülevaade}

\section{Õpetaja professionaalne areng}

Üldiselt mõistetakse arengut protsessina, mille käigus toimub psüühika kui terviku kvalitatiivne muutus läbi psüühiliste protsesside muutmise (Kõrgesaar, 2016; Toomela, 2016). Õpetajate toetamise kontekstis räägitakse konkreetsemalt õpetaja professionaalsest arengust (professional development) ja järjepidevast professionaalsest arengust (continuous professional development). Sealjuures ei defineerita aga üheselt mõistetavalt, mida need terminid täpsemalt tähendavad. Sageli kirjeldatakse õpetajate järjepidevat professionaalset arengut selle eesmärgi kaudu: aidata ópetajal teadvustada ja laiendada oma teadmisi, oskusi ja hoiakuid ning seostada neid igapäevase õpetamispraktikaga, et olla paremini ette valmistatud pidevalt muutuvate oludega hakkamasaamiseks (OECD, 2015; Timperley, 2008). Teinekord lähtutakse õpetaja professionaalse arengu selgitamisel hoopis õpilastest ning tuuakse välja, et õpetaja professionaalne areng aitab tagada õpilaste tõhusa ja püsiva õppimise toetamise (Borko, Jacobs, \& Koellner, 2010). Mõni autor määratleb õpetaja järjepidevat professionaalset arengut kui õppimisprotsessi, mis aitab kaasa muutustele õpetaja mõtlemises oma õpetamise kohta ja tema igapäevases praktikas (Kelchtermans, 2004). Niisiis osutatakse, et järjepidev professionaalne areng toetab õpetaja igapäevast toimetulekut, kuid ei selgitata, mis ja kuidas arengu jooksul täpsemalt muutub. Seega on terminite ópetaja professionaalne areng ja järjepidev professionaalne areng tähendus ebaselge ning puudub ühtne arusaam, mida õpetaja arengu toetamine täpselt tähendab.

Manchesteri ülikooli professor Linda Evans on oma artiklis „Mis on õpetaja areng?“ („What is teacher development?“, 2002) käsitlenud õpetaja arengu kui 
kontseptsiooni üheselt defineerimise olulisust ning tõdenud, et ei õpetaja professionaalse arengu olemust ega protsessi ei ole selgelt määratletud, mis jätab piisava tähelepanuta meetodid, mida võiks õpetaja arengu toetamiseks kasutada. Oma põhjalikus kirjanduse ülevaates toob ta välja, et enamasti räägivad haridusteadlased õpetaja professionaalsest arengust kui protsessist, mida iseloomustab professionaalse teadmise ja selle struktureerimise, tegevuse, vastutuse, kolleegide koostöö ning oma professionaalse rolli mõtestamise muutumine õpetamise uurimise ja analüüsimise käigus. Evans (2002) tõdeb oma ülevaate kokkuvõttes, et kuigi paljud autorid viitavad õpetaja arengu kontekstis sarnastele aspektidele, puudub terviklik arusaam, mis see täpsemalt siiski on. Seega pakub Evans välja oma definitsiooni, määratledes õpetaja arengut kui protsessi, mis võib olla sisemiselt või väliselt juhitud ning mis võib parendada õpetaja elukutse staatust ning õpetaja teadmisi, oskusi ja tööd. Sealjuures eristab ta õpetaja arengus kahte põhimõttelist komponenti, mis kajastavad arengu käigus toimuvate muutuste fookust: 1) suhtumisega seotud areng kui protsess, mille käigus muutub õpetaja suhtumine oma töösse; 2) tegevusega seotud areng kui protsess, mille käigus paraneb õpetaja professionaalne sooritus.

Evansi käsitluse kohaselt hõlmab suhtumisega seotud areng muutust seoses maailmatunnetuse ja motivatsiooniga, tegevusega seotud areng aga muutust seoses toimingutega, mida õpetaja teeb, ning nende tegevuste tulemuslikkusega. Veelgi enam, Evansi käsitluse järgi sisaldab areng muutust (aga ei koosne üksnes sellest), mida võib liigitada õppimise alla. Seega annab Evans oma definitsiooniga konkreetse struktuuri, kuidas mõista õpetaja professionaalset arengut, ning rõhutab sealjuures vajadust määratleda selle struktuuri sees universaalselt kohaldatavad õpetaja professionaalse arengu protsessi tunnused, mis aitavad kirjeldada, kuidas liiguvad õpetajad edasi ühelt tasemelt teisele.

Pikka aega erineva kogemusega õpetajaid uurinud hariduspsühholoog David Berliner on empiiriliste uuringute tulemusel eristanud tunnused, mis aitavad kirjeldada õpetaja professionaalse arengu toimumist. Täpsemalt on Berliner (1988) välja toonud õpetaja professionaalse arengu kui protsessi määratlemiseks järgmised tunnused: 1) klassiruumi tajumine, tõlgendamine ja prognoosimine; 2 ) oluliste sündmuste või olukordade eristamine tervikust; 3) rutiinide kasutamine; 4) vastutus oma tegevuse eest ja sellest tulenev emotsionaalne side. Peamiselt seostuvad need tunnused Linda Evansi (2002) määratluse järgi õpetaja professionaalse arengu tegevusega seotud komponendiga, mille kaudu paranevad arengu jooksul õpetaja tegevused ja nende tulemuslikkus. Küll aga on vastutuse ja sellest tuleneva emotsionaalse seotuse tunnus liigitatav professionaalse arengu suhtumisega seotud komponendi alla, peegeldades muutust õpetaja rollitunnetuses. Siinses artiklis mõistetakse õpetaja professionaalset arengut protsessina, mille tulemusel toimuvad kvalitatiivsed 
muutused nii õpetaja igapäevases praktikas kui ka vastutuse võtmises oma tegevuse eest. Alljärgnevalt antakse põgus ülevaade õpetaja professionaalse arengu protsessist Berlineri tunnuste kaupa, et paremini mõista, millised muutused toimuvad liikumisel ühelt professionaalse arengu etapilt teisele ja millist tuge õpetajad sellal vajavad.

Õpetajaks kujunemine algab enamasti õpetajakoolitusega, kus põhitähelepanu on valdkonnaspetsiifiliste teadmiste ja esmaste õpetamisoskuste omandamisel (Berliner, 2004; Simons \& Ruijters, 2014). Varasema kogemuse puudumise tõttu on alustaval õpetajal (novice teacher) keeruline klassiruumi tajuda, tõlgendada ja toimuvat prognoosida. Seetõttu vajab ta uute oskuste omandamisel olulisel määral välist tõuget ja tuge ning võimalusi korduvalt samu õpetamistegevusi harjutada (Berliner, 2001). Lisaks on sel etapil õpetaja põhitähelepanu temal endal (Beijaard, Meijer, \& Verloop, 2004; Fuller, 1969). Väline tugi on vajalik selleks, et õppida märkama õpetamissituatsiooni eri aspekte ning mõtestama kogemusi eri vaatenurkadest. Tänu väljastpoolt toetatud praktiliste kogemuste teadlikule mõtestamisele jõuab õpetaja esimeste tööaastate jooksul edasijõudnud algaja õpetaja tasemele (advanced beginner teacher).

Edasijõudnud algajat õpetajat eristab alustavast õpetajast varasemast suurema vastutuse võtmine ühelt poolt oma õpetamise, teiselt poolt enda kui õpetaja arengu toetamise eest üldisemalt; oskus püstitada põhjendatud eesmärke ja valida sobivad viisid nende saavutamiseks; oskus seada prioriteete, eristades tervikust olulisi sündmusi ja olukordi, millele tähelepanu pöörata ja reageerida (Berliner, 2001; 2004). Samuti on edasijõudnud algajale õpetajale iseloomulik, et oma kogemuste järjepideva mõtestamise kaudu õpitakse pöörama enam tähelepanu ka aine sisule ja õpetaja-õpilase suhetele (Beijaard et al., 2004; Berliner, 2004). Sel etapil vajab õpetaja järjepidevaid võimalusi ettetulevate olukordade mõtestamiseks varasemate teadmiste valguses, et märgata olukordade vahel sarnasusi. See aitab luua integreeritud teadmiste süsteemi, tõlgendada olukorras toimuvat ning prognoosida sündmuste võimalikku kulgu, et seeläbi teha otsuseid, kuidas edaspidi oma tegevusi juhtida.

Oma praktika pideva jälgimise ja mõtestamise kaudu, selle põhjal varasemate teadmiste seostamise ja uute teadmiste loomise varal saavutatakse kogenud õpetaja tase. Kogenud õpetajat iseloomustab teatud igapäevaste tegevusrutiinide loomine (Berliner, 2004). Kuna rutiinsed tegevused ei vaja efektiivseks toimimiseks õpetaja teadlikku tähelepanu, võimaldavad need õpetajal teadlikult keskenduda õpilaste õppimise toetamisele. Kogenud õpetajat eristab algajast õpetajast see, et ta juhib teadlikult nii enda tegevusi kui ka õppijate õppimist. Sel perioodil vajab õpetaja oma igapäevapraktika toetamiseks võimalusi ise aktiivselt enda kogemusi mõtestada (Desimone, 2009). Sealjuures muutub varasemast kesksemaks oma otsuste ja tegevuste mõtestamine õpilaste 
õppimise toetamise valguses (Borko et al., 2010). Pealegi on uurimused näidanud, et ka õpilased tajuvad kogenud õpetajate õpetamistegevusi tõhusamana kui algajate õpetajate omi (Okas, van der Schaaf, \& Krull, 2016). Samuti näitavad uurimused, et oma praktika tõhustamise ja rolli mõtestamise üks olulisi võtmekomponente on koostöö kolleegide vahel (Gellert, 2008; Timoštšuk, Ugaste, \& Mets-Alunurm, 2018). Seega on vaja luua kogenud õpetajatele ühelt poolt võimalusi arutada oma õpetamispraktikate üle üheskoos kolleegidega ja teiselt poolt võimalusi vaadelda kolleegide tegevusi, et seeläbi paremini mõtestada eri õpetamistegevuste ja lähenemiste seost õpilaste õppimise toetamisega (Timperley, 2008).

Enamik õpetajaid jääb kogenud õpetaja tasemele, kuid tõeline paindlikkus saavutatakse õpetamises ekspertõpetaja tasemele jõudmisega. Eksperte iseloomustab intuitiivsem ja implitsiitsem otsuste tegemine ning sujuv tegutsemine. „Eksperdid teevad asju, mis tavaliselt töötavad, ja seetõttu, kui asjad sujuvad, ei lahenda eksperdid probleeme ega tee otsuseid nende mõistete tavapärases tähenduses. Nad lähevad vooluga kaasa, nagu seda mõnikord kirjeldatakse" (Berliner, 2004, lk 208). Sel moel võib õpetajate tegevusse ringlema jääda ka ebatõhusaid ja iganenud praktikaid ning on väga tähtis, et õpetajad jätkaksid enda kursishoidmist valdkonna arenguga ja uuendaksid oma teadmiste pagasit (Leijen, Pedaste, \& Lepp, 2019; Simons \& Ruijters, 2014). Ekspertõpetajat iseloomustab oma teadmiste pidev kaasajastamine ja uute seoste loomine, mis muu hulgas tähendab oma teoreetiliste teadmiste pidevat täiendamist ja praktiliste kogemustega seostamist (Simons \& Ruijters, 2014). Eelnevast tulenevalt on ilmne, et õpetaja professionaalse arengu keskmes on oma kogemuste pidev mõtestamine ja seostamine. Refleksioon on peamine meetod praktilisest kogemusest õppimiseks. Alljärgnevalt antaksegi ülevaade refleksiooni olemusest ja peamistest toetamisviisidest.

\section{Refleksioon kui viis õpetaja professionaalse arengu toetamiseks}

Refleksioon on mõtlemisprotsess, mis aitab luua oma praktilisele kogemusele tuginedes uusi teadmisi kas individuaalselt või koostöös teistega (Dewey, 1933; Korthagen, 2004; Schön, 1983). Täpsemalt öeldes toimub refleksiooniprotsessi käigus oma kogemuste põhjalik lahtimõtestamine, et saada seeläbi teadlikuks oma automaatsetest käitumismustritest, hinnangutest ja vaikivatest normidest, mis mõjutavad tehtavaid otsuseid ja käitumist (Schön, 1983). Teadlikkuse kasvuga jõutakse refleksiooniprotsessi tulemusel harjumuspärase käitumise asemel eesmärgipäraste valikute tegemiseni, et juhtida teadlikult oma otsuseid ja käitumist ning seeläbi parendada oma igapäevast praktikat (Dewey, 1933; Husu, Toom, \& Patrikainen, 2008; Rodgers, 2002). Seega, kui mõtestada 
õpetaja professionaalset arengut protsessina, mille tulemusel toimuvad kvalitatiivsed muutused nii õpetaja igapäevases praktikas kui ka suhtumises, on refleksioon peamine viis õpetajate toetamiseks (Berliner, 2004; Cochran-Smith, 2003; Korthagen, 2004). Sealjuures on selliste kvalitatiivsete muutuste üks oluline ajend oma teadmiste pidev ümberkorraldamine ja kaasajastamine (Simons \& Ruijters, 2014).

Lisaks eespool kirjeldatud praktilise tegevuse mõtestamisele ja sellele tuginevalt uute teadmiste loomisele on refleksiooniprotsessi oluline osa teadmiste seostamine olemasoleva teadmiste süsteemiga, soodustades sel viisil sügavat õppimist ning kiiret ligipääsu loodud teadmistele (Billing, 2007; Moon, 2004). Seega aitab reflekteerimine seostada mõtestatult uued teadmised olemasolevasse teadmiste struktuuri nii, et need saavad osaks nendest teadmistest, mida kasutatakse aktiivselt igapäevaste otsuste langetamisel ja tegevuste juhtimisel. Seetõttu on refleksioon tõhus viis õpetaja professionaalse arengu toetamiseks. Samas rõhutavad uurijad, et reflekteerimisoskus ei kujune iseenesest õpetajad vajavad hästi läbimõeldud toetust (Shulman \& Shulman, 2004). Seega on vaja leida tõhusad meetodid refleksiooni toetamiseks. Alljärgnevalt kirjeldatakse aspekte, mis on empiiriliste uurimuste põhjal osutunud refleksiooni toetamisel tõhusaks.

Uuringutes on välja toonud aspekte, mille lisamine reflekteerimise protsessi on toetanud oma kogemuse tulemuslikumat mõtestamist ja teadmiste süsteemi tõhusamat ümberkorraldamist. Esiteks on leitud, et reflekteerimist toetab isiklikult tähenduslikele olukordadele keskendumine (Husu et al., 2008; Meijer, de Graaf, \& Meirink, 2011; Tripp, 1993). Ühelt poolt kindlustab tähenduslike olukordade valimine valmisoleku refleksiooniprotsessi panustada ning teiselt poolt seab see refleksioonile selgepiirilise fookuse, võimaldades luua konkreetseid seoseid teadmiste vahel.

Teiseks on uurimused (Borko et al., 2008; Leijen, Lam, Wildschut, \& Simons, 2009; Zhang, Lundeberg, Koehler, \& Eberhardt, 2011) näidanud, et reflekteerimist toetab oma õpetamise videosalvestiste kasutamine. Nimelt võimaldab videosalvestis jälgida olukorda eri vaatenurkadest, kaotamata seejuures tervikpilti.

Kolmandaks on leitud, et kaaslasega reflekteerimine on tõhusam (Brennamar, 2004; Leijen, Valtna, Leijen, \& Pedaste; 2012; Meijer, Zanting, \& Verloop, 2002; Procee, 2006). Täpsemalt loob see olukorra, kus on vaja oma mõtteid sõnastada. Sõnastamine võimaldab oma mõtteid jälgida, parandada ja täiendada. Teisalt annab koos kaaslasega reflekteerimine võimaluse tutvuda kõrvalseisja tähelepanekute ja vaatenurkadega.

Neljandaks on uurimustulemused välja toonud, et reflekteerimist toetavad suunavad küsimused ja stimuleeritud meenutuse meetodil intervjuu. Täpsemalt 
loovad need toetava struktuuri oma kogemuse mõtestamiseks, suunavad tooma põhjendusi ja looma seoseid ning aitavad reflekteerides keskenduda konkreetsele olukorrale (Husu et al., 2008; Korthagen \& Vasalos, 2005; Meijer et al., 2002; Sööt \& Leijen, 2012). Seega on olemas tõenduspõhised võtted refleksiooni toetamiseks, kuid ei ole piisavalt meetodeid, mis seoks need tervikuks.

Eelnevale tuginedes töötati Euroopa Liidu elukestva õppe programmi Comenius projekti ACTTEA raames 2012. aastal ühes Helsingi, Turu, Utrechti ja Salamanca ülikooli õpetajahariduse uurijatega välja suunatud refleksiooni protseduur (Allas et al., 2017). Selle projekti eesmärk oli toetada õpetajakoolituse üliõpilaste reflekteerimist nii, et nad jõuaksid refleksiooniprotsessi tulemusel sellise teadmiseni, mida nad kasutavad õpetajana oma igapäevaste otsuste langetamisel ja praktika juhtimisel. Projekti raames välja töötatud suunatud refleksiooni protseduuri lõimiti eespool nimetatud refleksiooni toetamise aspektid.

Esiteks on refleksiooniprotseduur jaotatud neljaks etapiks. Refleksiooniprotsessi ajaline jaotus aitab reflekteerijal olukorrast distantseeruda ning vaadata seda mitmest vaatenurgast. Samuti võimaldavad eri etapid oma kogemust korduvalt mõtestada, mis soodustab seoste ja põhjenduste loomist ning seeläbi teadmiste ümberkorraldamist viisil, mis muudab need edaspidi kergesti kättesaadavaks. Teiseks on refleksiooniprotseduuri üks osa oma tegevuse filmimine. Õpetamise videosalvestise läbivaatamine võimaldab ühelt poolt märgata seda, mis ehk õpetades jääb tähelepanuta, ja teiselt poolt saada oma tegevusest tervikpilti. Ühtlasi võimaldab videosalvestis õpetamist eri vaatenurkadest korduvalt üle vaadata. Kolmandaks toetab see refleksiooniprotseduur reflekteerija välja valitud tähenduslike olukordade mõtestamist. Nii annab tähenduslike olukordade valimine vastutuse reflekteerijale - tema otsustab, millega ta tahab põhjalikumalt tegeleda. Teisalt aitab tähenduslike olukordade valimine hoida selget fookust, mille üle sügavuti mõelda. Neljandaks rakendatakse selles refleksiooniprotseduuris oma kogemuse mõtestamise ja uute teadmiste loomise toetamiseks suunavaid küsimusi ja stimuleeritud intervjuu meetodit ehk videosalvestise abil teadvustatakse mõtteid ja tundeid, mis olid reflekteerijal õpetamise ajal. Suunavad küsimused ja stimuleeritud meenutuse intervjuu aitavad refleksiooni käigus keskenduda konkreetsele olukorrale ning suunavad looma seoseid ja tooma põhjendusi. Viiendaks kaasab see refleksiooniprotseduur reflekteerimise protsessi välise toe ehk kõrvalseisja isiku, kes esitab suunavaid küsimusi, aitab näha erinevaid vaatenurki ja loob võimaluse oma mõtted selgelt sõnastada, et neid vajaduse korral korrastada ja ümber korraldada.

Erinevalt varasematest refleksiooniprotseduuridest (nt Husu et al., 2008, millel põhineb siinne suunatud refleksiooni protseduuri struktuur) ühendab 
see protseduur refleksiooni toetamise aspektid terviklikuks meetodiks ning protseduuri suunavad küsimused on koostatud nii, et need toetaksid õpetajatööks vajalike teadmiste loomist. Välja töötatud protseduuri katsetati õpetajakoolituse üliõpilastega Eestis, Soomes, Hollandis ja Hispaanias ning uurimuste (Allas et al., 2017; Knezic et al., 2019; Toom et al., 2019) tulemused kinnitasid, et protseduur toetab õpetajakoolituse üliõpilasi oma kogemuste mõtestamisel ja teadmiste korrastamisel.

Kuigi üliõpilaste hulgas tehtud uuringud annavad alust oletada, et suunatud refleksiooni protseduur võiks sobida ka tegevõpetajate refleksiooni toetamiseks, tuleb siiski meeles pidada, et õpetajate vajadused on professionaalse arengu eri etappidel erinevad (Berliner, 2004) ja vaja on lisauuringut, et selgitada välja, kuidas tajuvad sama refleksiooni toetamise meetodit õpetajad, kes on professionaalse arengu eri etappidel. Seetõttu võrreldakse siinses uurimuses professionaalse arengu eri etappidel olevate õpetajate kogemusi ACTTEA projekti raames välja töötatud refleksiooniprotseduuriga, et anda läbilõige, millised on suunatud refleksiooni protseduuri kasutegurid ja kitsaskohad erinevate kogemustega õpetajate hinnangul. Täpsemalt püstitati kaks uurimisküsimust: 1) mis on suunatud refleksiooni protseduuri rakendamise peamised kasutegurid õpetajakoolituse üliõpilaste ja õpetajate hinnangul; 2) mis on suunatud refleksiooni protseduuri rakendamise peamised kitsaskohad õpetajakoolituse üliõpilaste ja õpetajate hinnangul.

\section{Meetod}

\section{Valim}

Selleks, et kirjeldada, kuidas tajuvad erinevatel professionaalse arengu etappidel olevad õpetajad suunatud refleksiooni protseduuri kasutegureid ja kitsaskohti, tehti kaks uurimust. Alljärgnevalt kirjeldatakse mõlema uurimuse osalejaid.

\section{Uurimus I}

Esimene uurimus keskendus õpetaja professionaalse arengu esimesele etapile ehk õpetajakoolitusele ning see hõlmas 21 üliõpilast kolmelt õppekavalt: koolieelse lasteasutuse õpetaja õppekava $(\mathrm{n}=7)$, põhikooli mitme aine õpetaja õppekava $(n=8)$ ja klassiõpetaja õppekava $(n=6)$. Osalejad valiti uurimusse kriteeriumvalimi põhimõttel (Patton, 1990) - kõik uurimuses osalenud üliõpilased sooritasid andmekogumise ajal oma kohustuslikku õpetamispraktikat. Sealjuures olid üliõpilased õpingute ja praktikaga eri etappides. Koolieelse lasteasutuse õpetaja õppekava üliõpilased olid bakalaureuseõppe viimasel ehk kolmandal aastal ja nad olid sooritamas viimast diplomipraktikat. Klassiõpetaja 
õppekava üliõpilased olid integreeritud bakalaureuse- ja magistriõppe neljandal aastal ja nad läbisid teise kooliastme praktikat. Seega oli mõlema õppekava üliõpilastel varasem õpetamispraktika kogemus. Põhikooli mitme aine õpetaja õppekava üliõpilased olid magistriõppe esimesel aastal ning omandamas päris esimest õpetamispraktika kogemust.

Uurimuses rakendatud suunatud refleksiooni protseduur oli integreeritud üliõpilaste praktikaülesannetesse. Klassiõpetaja ja põhikooli mitme aine õpetaja õppekava üliõpilastel oli suunatud refleksiooni protseduur õpetamispraktika kohustuslik osa ning koolieelse lasteasutuse õpetaja õppekava üliõpilastel oli see vabatahtlik praktikaülesanne. Sellegipoolest oli uurimuses osalemine üliõpilastele vabatahtlik ja neil oli võimalus loobuda uurimuses osalemisest, sooritades suunatud refleksiooni protseduur lihtsalt praktikaülesandena. Kõik uurimuses osalenud üliõpilased olid naissoost ning nende keskmine vanus oli 25.

\section{Uurimus II}

Teine uurimus keskendus töötavatele õpetajatele ning selles uurimuses osales 80 õpetajat haridusasutustest üle kogu Eesti: lasteaedadest $(n=44)$, üldhariduskoolidest $(n=33)$, kutsekoolidest $(n=2)$, huvikoolist $(n=1)$. Ka selles uurimuses moodustati valim kriteeriumvalimi põhimõttel (Patton, 1990) uurimuses osalesid õpetajad, kes läbisid andmekogumise ajal mentorõpetajatele suunatud refleksiooniteemalist täienduskoolitust. Sealjuures oli uurimuses osalevatel õpetajatel erinev töö- ja üliópilaste praktika juhendamise kogemus. Koolitusel osales nii algajaid õpetajaid, kelle tööstaaž oli alla viie aasta ja kellel puudus üliõpilaste juhendamise kogemus, kui ka kogenud õpetajaid, kellel oli ka pikaajaline mentorõpetaja kogemus. Kuigi uurimuses rakendatud suunatud refleksiooni protseduur oli koolituse kohustuslik osa, oli igal õpetajal võimalus uurimuses mitte osaleda. Ükski õpetaja seda võimalust ei kasutanud. Lisaks oli õpetajatel võimalus valida, kas nad soovivad suunatud refleksiooni protseduuri läbi teha ise oma õpetamispraktikat mõtestades või toetades oma kolleegi või üliõpilast tema õpetamiskogemuse mõtestamisel. Kokku osales uurimuses 78 naisõpetajat ja 2 meesõpetajat, kelle keskmine vanus oli 45 aastat. Statistika järgi on keskmine Eesti õpetaja 49-aastane (OECD, 2019), mis on mõnevõrra kõrgem vanus kui siinse valimi puhul.

\section{Andmekogumine}

Uurimuse eesmärk oli kirjeldada ja võrrelda, kuidas tajuvad õpetajad professionaalse arengu eri etappidel suunatud refleksiooni protseduuri kasutegureid ja kitsaskohti. Andmeid õpetajate hinnangute kohta koguti poolstruktureeritud tagasisideintervjuude ja poolstruktureeritud rühmaaruteludega. Allpool 
kirjeldatakse suunatud refleksiooni protseduuri, mille kohta õpetajad hinnanguid andsid, ning intervjuude ja rühmaarutelude korraldamist, millega õpetajatelt uurimustes hinnanguid koguti.

Suunatud refleksiooni protseduur. Uurimuse käigus koguti osalejatelt tagasisidet nende kogemuse kohta suunatud refleksiooni protseduuriga. Seega oli andmete kogumise eelduseks, et osalejad teevad läbi suunatud refleksiooni protseduuri. Nagu eespool kirjeldatud, tegid esimeses uurimuses õpetajakoolituse üliõpilased suunatud refleksiooni protseduuri läbi oma õpetamispraktika raames ning teises uurimuses tegid õpetajad protseduuri läbi täienduskoolituse raames. Sealjuures oli õpetajatel võimalus valida, kas nad teevad suunatud refleksiooni protseduuri ise läbi või toetavad selle protseduuri läbitegemisel oma üliõpilast, algajat kolleegi või kogenud kolleegi. Uurimustes rakendatud suunatud refleksiooni protseduur on esitatud joonisel 1.

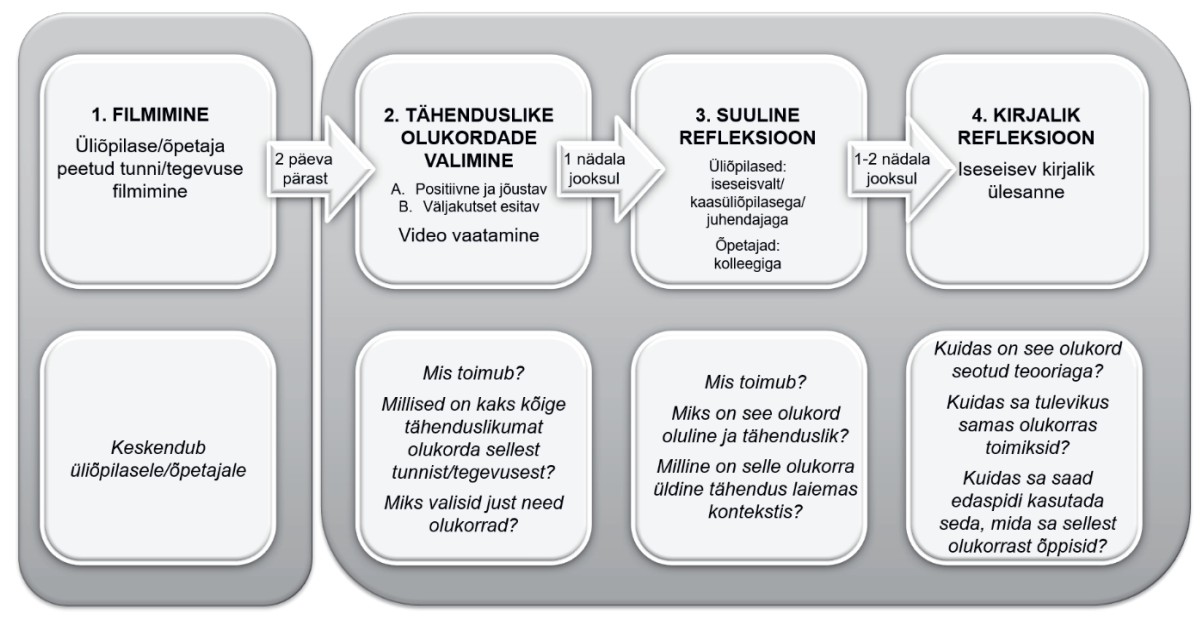

Joonis 1. Suunatud refleksiooni protseduur (Allas et al., 2017; kohandatud Husu et al., 2008 järgi).

Uurimuses rakendatud suunatud refleksiooni protseduur koosneb neljast etapist. Esimeses etapis valivad osalejad ühe tunni või tegevuse, mida nad filmivad. Osalejaid julgustatakse valima filmimiseks see tund või tegevus, mis on seotud nende isiklike õpetamiseesmärkidega. Samuti juhendatakse osalejaid koguma enne filmimist kõikidelt osalistelt informeeritud nõusolek. Teises etapis vaatavad osalejad oma õpetamise videosalvestise läbi ja valivad selle põhjal kaks olukorda, mille üle järgnevalt põhjalikumalt reflekteerida. Sealjuures suunatakse osalejaid valima ühte olukorda, millega nad rahule jäid, ja teist olukorda, mida nad sooviksid muuta. Osalejaid julgustatakse valima just neid olukordi, mis on nende jaoks isiklikult tähenduslikud ja kooskõlas endale 
seatud eesmärkidega. Kolmandas etapis arutlevad osalejad etteantud küsimustele tuginedes teises etapis valitud kahe tähendusliku olukorra üle.

Esimeses uurimuses oli üliõpilastel võimalus valida, kas nad soovivad suulist refleksiooni teha üksi, kaasüliõpilasega või praktikajuhendajaga. Teises uurimuses tegid osalejad suulise refleksiooni läbi ise kolleegi suunamisel või toetasid üliõpilase, noore kolleegi või kogenud kolleegi suulist refleksiooni. Suulise refleksiooni eesmärk on mõelda välja valitud olukordadele eri vaatenurkadest ja arutleda õpetaja tegevuste võimalike tagamaade üle. Neljandas etapis mõtestavad osalejad teises etapis välja valitud ja kolmandas etapis läbi arutatud olukorrad veel kord iseseisva kirjaliku refleksioonina lahti, toetudes etteantud küsimustele. Kirjaliku refleksiooni eesmärk on suunata osalejaid looma seoseid teoreetiliste teadmiste ja välja valitud tähenduslike olukordade üle ning integreerima refleksiooniprotsessist saadud teadmisi oma isiklike põhimõtete ja eesmärkidega.

\section{Uurimus I}

Poolstruktureeritud tagasiside-intervjuud. Esimeses uurimuses koguti õpetajakoolituse üliõpilaste tagasisidet suunatud refleksiooni protseduuri läbitegemise kogemuse kohta poolstruktureeritud intervjuudega. Intervjuud toimusid kahekuni neljaliikmeliste rühmaintervjuudena pärast seda, kui osalejad olid kogu protseduuri läbi teinud. Rühmaintervjuu eesmärk oli koguda ühiselt jagatud arvamusi. Intervjuud toimusid väljaspool üliõpilaste õppetööaega. Viiel üliõpilasel ei olnud aga võimalik rühmaintervjuus osaleda, mistõttu koguti nendelt tagasisidet eraldi $(n=2)$ või kirjaliku intervjuuna $(n=3)$. Sealjuures olid üliõpilaste arvamused suunatud refleksiooni protseduurist võrdlemisi sarnased, sõltumata sellest, kas tagasiside koguti kirjalikult, rühma- või individuaalse intervjuuna. Kõik intervjuud audiosalvestati osalejate nõusolekul.

\section{Uurimus II}

Poolstruktureeritud rühmaarutelud. Teises uurimuses koguti õpetajate tagasisidet suunatud refleksiooni protseduuri läbitegemise kohta poolstruktureeritud rühmaarutelude käigus. Tagasiside kogumine toimus viimase koolituspäeva ühe osana. Rühmaarutelud olid üles ehitatud kahes etapis. Esiteks arutasid osalejad väikestes rühmades, mis olid suunatud refleksiooni protseduuri läbitegemise kasutegurid ja kitsaskohad ning kuidas nad seda protseduuri edasi arendaksid. Väikerühmad moodustati selle põhjal, kuidas õpetajad suunatud refleksiooni protseduuri läbi tegid: enda õpetamiskogemust mõtestades, oma üliõpilast, algajat kolleegi või kogenud kolleegi toetades. Iga väikerühm koostas arutelu põhjal plakati, kuhu kanti peamised kasutegurid, kitsaskohad ja arendusettepanekud. Kuigi osalejatel oli täielik vabadus valida, kuidas 
nad soovivad suunatud refleksiooni protseduuri läbi teha, jaotusid osalejad erinevate võimaluste vahel võrdlemisi ühtlaselt - ükski moodustunud väikerühm ei olnud teistest märgatavalt suurem ega väiksem. Teiseks andis iga väikerühm ülevaate oma tagasisidest kogu rühmale, lisades vajaduse korral selgitusi ja täpsustusi. Väikerühmade ettekannetele järgnes ühine arutelu, mille lõpus koguti osalejate nõusolekul kokku kõikide väikerühmade plakatid. Kokku moodustati andmekogumise käigus 15 väikerühma, kelle koostatud plakatid kodeeriti tähistega G1-G15. Ühtlasi tegi uurija arutelude ajal jooksvalt märkmeid uurija logisse, et jäädvustada mõtted, mis ei olnud plakatitele üles märgitud. Andmekogumise käigus ilmnes, et õpetajad, kes tegid suunatud refleksiooni protseduuri läbi iseenda õpetamiskogemust mõtestades, olid kogenud õpetajad. Siinses uurimuses käsitletakse kogenud õpetajatena osalejaid, kelle tööstaaž oli üle kümne aasta. Seega koguti nende kahe väikerühma andmeid eraldi, kuid andmete analüüsimisel vaadati neid ühe rühmana.

\section{Andmeanalïïs}

Osalejatelt kogutud tagasiside analüüsimiseks kasutati induktiivset temaatilist sisuanalüüsi (Ryan \& Bernard, 2003), mis võimaldab märkida osalejate tagasisides esile kerkivaid ilminguid sedamööda, mis andmetest välja tuleb, ilma et uurija oleks otsitavat varem kindlaks määranud. Andmete analüüsimine toimus kolmes etapis. Esiteks transkribeeriti täies mahus esimeses uurimuses kogutud intervjuude salvestised ning need analüüsiti koos kolmelt osalejalt kogutud kirjaliku tagasisidega. Esmase analüüsi käigus eristati üliõpilaste tagasisides korduvad teemad ja alateemad, mis organiseeriti laiemate kategooriate alla. Pärast kategooriate moodustamist analüüsiti kõik üliõpilastelt kogutud andmed uuesti läbi, et tagada andmeanalüüsi vastavus välja töötatud kategooriatele. Sealjuures rakendati andmeanalüüsi usaldusväärsuse tagamiseks uurijatevahelist triangulatsiooni (Denzin, 1970). Teises etapis analüüsiti teises uurimuses õpetajatelt kogutud tagasisidet sarnaselt üliõpilastelt kogutud tagasiside analüüsimisega. Kolmandas etapis analüüsiti mõlemas uurimuses kogutud andmed uuesti läbi, et võrrelda esimese ja teise uurimuse andmete analüüsimisel loodud kategooriaid ning need ühtlustada.

\section{Tulemused}

Artikli eesmärk oli kirjeldada, kuidas tajuvad õpetajad professionaalse arengu eri etappidel suunatud refleksiooni protseduuri kasutegureid ja kitsaskohti. Selleks koguti ja analüüsiti õpetajakoolituse üliõpilaste ja õpetajate tagasisidet. Alljärgnevalt esitatakse uurimuste peamised tulemused uurimisküsimuste kaupa. 


\section{Suunatud refleksiooni protseduuri rakendamise kasutegurid õpetajakoolituse üliõpilaste ja õpetajate hinnangul}

Üldiselt oli erinevatel õpetajate hinnang suunatud refleksiooni protseduuri läbitegemise kogemusele positiivne. Nad tundsid, et see aitas neil põhjalikumalt õpetamist mõtestada ning pakkus vajalikku tuge, et tõlgendada oma tegevust ja selle üle arutleda. Seda arvamust illustreerib nende õpetajate välja toodud mõte, kes toetasid oma algajaid kolleege suunatud refleksiooni protseduuri läbitegemisel, rõhutades, et tegemist oli väga kasuliku kogemusega, mida ollakse valmis igal aastal kordama. Samuti tõid kogenud õpetajad esile, et refleksiooniprotseduuri läbitegemine aitas kaasa muutuste toimumisele. Täpsemalt tõid osalejad välja viis peamist kasutegurit, mis nende hinnangul kaasnes suunatud refleksiooni protseduuri läbitegemisega: kõrvaltvaataja vaatenurk, kaaslase tugi, muutused praktikas, refleksiooni sügavus, enese jõustamine. Järgnevalt kirjeldatakse põhjalikumalt iga osalejate välja toodud kasutegurit.

Kõrvaltvaataja vaatenurk. Õpetajad hindasid kõrgelt võimalust näha ennast ja enda õpetamist kõrvalt, mida võimaldas videosalvestise kasutamine. Täpsemalt tõid õpetajad välja, et videosalvestis aitab ennast õpetajana paremini tundma õppida ja näha tegelikke õpetamissituatsioone. Nii näiteks tõid kogenud õpetajad välja, et „filmimine on väga õpetlik; see, mis vastu peegeldub, on väga aus" (G11). Ühelt poolt väärtustasid õpetajad võimalust ennast jälgida, et märgata enda tugevusi ja aspekte, mida edasi arendada. Teiselt poolt rõhutasid õpetajad detailsemat õpilaste jälgimise võimalust, mis tegelikes õpetamissituatsioonides sageli puuduvad.

Kaaslase tugi. Õpetajad rõhutasid suunatud refleksiooni protseduuri läbitegemise ühe olulise kasutegurina koostööd kaaslasega. Kogenud õpetajad rõhutasid võimalust arutleda oma õpetamissituatsioonide üle kolleegiga. Nad hindasid võimalust näha enda välja valitud olukordi kaaslase vaatenurgast, saada positiivset tagasisidet ning kasulikke soovitusi oma praktika parendamiseks. Ka õpetajakoolituse üliõpilased ning algajaid õpetajaid toetanud osalejad kirjeldasid kaaslase toetavat rolli, mis suunas refleksiooni sügavamale. Sealjuures tõid nad välja, et protseduuri ülesehitus toetas koostööd. Näiteks selgitasid algajaid õpetajaid toetanud osalejad, et „õpetaja oli avatum - vastab, küsib, arvab" (G5). Seetõttu saavutati osalejate hinnangul kaaslasega parem kontakt, mis soodustas omavahelist koostööd.

Muutused praktikas. Õpetajakoolituse üliõpilaste ja kogenud õpetajate hinnangul aitas suunatud refleksiooni protseduuri läbitegemine sisse viia soovitud muudatusi oma õpetamispraktikasse. Sealjuures nägid nad muudatusi soodustavate kasuteguritena nii võimalust näha enda õpetamist videosalvestiselt, kaaslasega arutleda kui ka kirjaliku refleksiooni käigus saadud kogemusele tagasi vaadata. Seda illustreerivad kogenud õpetajate väljendatud 
mõtted, et „kogetu põhjal saab positiivseid muutusi teha“ (G15) ning „kirjalik refleksioon viis käitumise/olukorra lahendamiseni“ (G2). Ka üliõpilasi toetanud osalejaid tõid välja, et kokkuvõttev kirjalik refleksioon andis aega mõtisklemiseks ning saadud teadmiste kinnistamiseks, mis viis muutuseni õpetamispraktikas.

Refleksiooni sügavus. Õpetajakoolituse üliõpilased ja osalejad, kes toetasid oma üliõpilase või algaja kolleegi reflekteerimist, rõhutasid, et protseduur toetab sügavamat reflekteerimist. Ühelt poolt tõid nad välja, et videosalvestis ja tähenduslike olukordade valimine aitas võtta oma tegevuse eest suuremat vastutust. Teiselt poolt leidsid nad, et samade olukordade korduv mõtestamine aitas põhjalikumalt oma tegevust mõtestada ning soodustas saadud teadmiste kinnistamist. Nii näiteks tõid üliõpilast toetanud osalejad välja, et „mudeli suunavad küsimused aitasid refleksiooni põhjalikumaks“ (G3) ning algajat kolleegi toetanud osalejad, et „positiivne on see, et see annab aja mõelda ja enda mõtteid kujundada" (G5). Kuigi ka mõned kogenud õpetajate rühmad tõid välja, et protseduuri sisse planeeritud ajaline distants võimaldab paremini jõuda üldistuste ja analüüsini ning selle struktuur toetab oma kogemuse põhjalikku läbimõtlemist, ei rõhutanud nemad refleksiooni sügavuse aspekti nii tugevalt kui teised rühmad.

Enese jõustamine. Kogenud õpetajate ja õpetajakoolituse üliõpilaste hinnangul oli suunatud refleksiooni protseduuri läbitegemine jõustav. Ühelt poolt tundsid nad, et tähenduslike olukordade valimine aitas neil märgata ja keskenduda oma õpetamise positiivsetele aspektidele. Nii näiteks tõid üliõpilase reflekteerimist toetanud osalejad välja, et „õnnestumiste nägemine andis positiivse laengu, enesekindluse; väljakutset pakkunud olukorra nägemine aga õppimiskoha" (G3). Teiselt poolt rõhutasid nad kaaslasega arutamise kasulikkust, mida illustreerib kogenud õpetajate välja toodud mõte, et „suuline refleksioon oli inspireeriv, tasakaalustab enesekriitikat" (G11).

Kokkuvõttes võib öelda, et õpetajad hindavad suunatud refleksiooni protseduuri kasutegureid sarnaselt, sõltumata sellest, millises professionaalse arengu etapis nad parasjagu on. Õpetajad väärtustavad protseduuri integreeritud refleksiooni toetamise viise, nagu kaaslasega reflekteerimine, videosalvestise kasutamine, tähenduslike olukordade valimine ning ajaline distants. Õpetajate hinnangul aitab refleksiooniprotseduuri läbitegemine viia muutusteni igapäevases praktikas, mis on professionaalse arengu toetamise meetodite üks peamisi eesmärke. 


\section{Suunatud refleksiooni protseduuri rakendamise kitsaskohad õpetajakoolituse üliõpilaste ja õpetajat hinnangul}

Kuigi üldiselt oli suunatud refleksiooni protseduuri läbitegemine õpetajate hinnangul neid toetav ning nad väljendasid oma valmisolekut seda protseduuri korrata, tõid nad välja kolm kitsaskohta, mida nad kogesid: ebakindlus seoses teoreetiliste teadmistega, aja leidmine, suunavatest küsimustest arusaamine. Järgnevalt kirjeldatakse täpsemalt iga osalejate välja toodud kitsaskohta.

Ebakindlus seoses teoreetiliste teadmistega. Kõik osalejad tõid välja, et vähemalt mingil määral kogesid nad ebakindlust teoreetiliste teadmiste seostamisel välja valitud tähenduslike olukordadega kirjaliku refleksiooni etapis. Sealjuures oli osalejate esile toodud kitsaskoht mõnevõrra erinev, sõltudes sellest, kui kaua on nad õpetajana töötanud. Kogenud õpetajate väljendatud ebakindlus oli seotud hirmuga, et nende teoreetilised teadmised on vananenud, mistõttu ei olnud nad kindlad, millistele teoreetilistele teadmistele tugineda. Väiksema tööstaažiga õpetajad aga tundsid pigem, et nende teoreetilised teadmised on liiga üldised, ja nad tundsid puudust piisavalt konkreetsetest teadmistest, mida oma kogemuste mõtestamiseks kasutada. Kuigi üliõpilasi või algajaid õpetajaid toetanud osalejad leidsid, et suunatud refleksiooni protseduur toetab seoste loomist praktika ja teooria vahel, kogesid ise protseduuri läbi teinud osalejad selles etapis raskusi. Samas väljendasid õpetajad soovi ja valmisolekut teoreetiliste teadmiste seostamiseks praktilise kogemusega. Nii näiteks tõid kogenud õpetajad välja, et „kasuks tuleks nimekiri olulisematest teooriatest/ autoritest/raamatutest/“ (G11). Samuti soovitati lisada protseduuri täiendavaid küsimusi, mis toetaks teoreetiliste teadmiste leidmist.

Aja leidmine. Teises uurimuses osalenud õpetajad tõid välja, et nende jaoks oli keeruline leida aega refleksiooniprotseduuri etappide läbitegemiseks. Üks kogenud õpetajate rühm sõnastas selgelt, et „keeruline oli aja leidmine ja enda kokkuvõtmine“ (G2). Teises uurimuses osalenud õpetajad tegid protseduuri läbi oma põhitöö kõrvalt. Esimeses uurimuses osalenud üliõpilased sooritasid protseduuri õpetamispraktika raames. Nemad ei toonud ajafaktorit kitsaskohana nii selgelt välja. Samas pakkusid teise uurimuse osalejad välja ka lahendusi, kuidas seda kitsaskohta ületada. Näiteks rõhutasid osalejad protseduuri kasutegurite teadvustamist, mis motiveerib selleks aega võtma. Näiteks tõid üliõpilaste refleksiooni toetanud osalejad esile, et tuleks ,pöörata aeg enda kasuks. Me juhendame tuleviku õpetajaid - meie tuleviku õpetajaid - meie tulevik sõltub nendest. See aeg tuleks leida“ (G8). Samuti soovitasid osalejad seada endale konkreetne ajaline piir ja teha ajakava.

Suunavatest küsimustest arusaamine. Mitmed osalejad, kes tegid suunatud refleksiooni protseduuri läbi oma üliõpilast või algajat kolleegi toetades, tõid 
välja, et suunavatest küsimustest arusaamine oli keeruline. Samal ajal leidsid aga üliõpilased, kes selle protseduuri esimeses uurimuses ise läbi tegid, et küsimused olid selged ning kaaslane aitas neist vajaduse korral paremini aru saada.

Põhikooli mitme aine ópetaja óppekava üliópilaste spetsiifiline tagasiside. Esimese uurimuse andmeid analüüsides eristus põhikooli mitme aine õpetaja õppekava üliõpilaste rühm. Tegemist oli üliõpilastega, kes olid sooritamas oma päris esimest õpetamispraktikat ning andsid sel ajal, kui nad suunatud refleksiooni protseduuri läbitegemise raames oma tegevust filmisid, oma päris esimest koolitundi. Seega oli sel ajal nende üliõpilaste peamine eesmärk tundi andes saada üldine kogemus, mis on õpetamine. Lisaks ei järgnenud nende tehtud ja filmitud tegevusele edasisi õpetamisvõimalusi, mis aidanuks läbitehtud suunatud refleksiooni protseduuri kogemuse põhjal oma praktikat parendada. Seega sellel ajal üliõpilaste hinnangul suunatud refleksiooni protseduuri läbitegemine neid ei toetanud. Kõige enam väärtustasid nad sellal praktikajuhendaja antud tagasisidet ja temalt saadud toetust. Samas tõid nad välja, et see protseduur võiks olla kasulik hilisemas etapis.

Kokkuvõttes oli peamine kitsaskoht, mida õpetajad professionaalse arengu eri etappidel nimetasid seotud teoreetiliste teadmiste seostamisega praktilise kogemusega.

\section{Arutelu}

Siinse töö eesmärk oli kirjeldada, kuidas tajuvad õpetajad professionaalse arengu eri etappidel suunatud refleksiooni protseduuri kasutegureid ja kitsaskohti. Uurimuse tulemused viitavad, et üldiselt hindavad professionaalse arengu eri etappidel olevad õpetajad selle protseduuri läbitegemise kogemust kasulikuks. See tulemus on oluline, sest järjepideva professionaalse arengu toetamise üheks suureks kitsaskohaks peetakse seda, et õpetajad ei taju pakutavate meetodite kasulikkust oma igapäevase tegevuse toetamisel (Borko et al., 2010; OECD, 2009). Kui aga õpetaja tajub, et rakendatav meetod teda igapäevases õpetamises aitab, siis on ta enam motiveeritud sellele aega võtma ja sellesse panustama. Siinse uurimuse osalejad rõhutasid, et nad on valmis suunatud refleksiooni protseduuri veel kord rakendama ning sellest saadud kasu igapäevase praktika toetamiseks tasakaalustab protseduuri läbitegemise ajalise faktori. Veelgi enam, osalejad tõid välja, et selle protseduuri läbitegemise kogemus oli jõustav, aidates neil iseennast õpetajana paremini tundma õppida, ning andis tõuke tegemaks muutusi oma igapäevapraktikas. Kuna järjepideva professionaalse arengu toetamise üks võtmekomponente on selle tihe seos õpetaja igapäevatööga (Borko et al., 2010) ning õpetaja professionaalne areng 
on seotud oma praktika parendamisega (Evans, 2002; Berliner, 2004), viitavad tulemused, et see meetod on potentsiaalselt sobilik õpetajate toetamiseks professionaalse arengu eri etappidel.

Uurimuses rakendatud suunatud refleksiooni protseduur sisaldas mitut refleksiooni toetamise aspekti: oma õpetamise videosalvestis, tähenduslike olukordade valimine, kaaslase tugi, suunavad küsimused, ajaline distants. Osalejate tagasiside viitab sellele, et see mudel võimaldab keskenduda eri aspektidele - nii saavad õpetajad just sellist tuge, mida nad oma professionaalse arengu etapis kõige rohkem vajavad. Algajatele õpetajatele on oluline väline tugi ja võimalus võtta õpetamissituatsioonid võtmekomponentideks lahti, et seeläbi omandada eduka õpetamise baasoskused (Berliner, 2004). Suunatud refleksiooni protseduuri integreeritud oma õpetamise videosalvestise kasutamine võimaldab algajal õpetajal näha õpetamissituatsioone eri vaatenurkadest ning vajaduse korral korduvalt sama kogemust lahti mõtestada. Tähenduslike olukordade valimine seevastu aga aitab õpetajal valida konkreetse fookuse, et samm-sammult uusi teadmisi ja oskusi kujundada. Lisaks aitavad suunavad küsimused ning suulise ja kirjaliku refleksiooni etapi ülesehitus väljastpoolt toetada õpetaja reflekteerimist, soodustades oma tegevuste põhjendamist ja seoste loomist erinevat tüüpi teadmiste vahel. Sealjuures on oluline tähelepanu pöörata uurimusest ilmnenud aspektile, mis viitab teatud praktilise kogemuse olemasolu vajalikkusele, et efektiivselt rakendada mudelisse integreeritud refleksiooni toetamise võimalusi.

Kogenud õpetajate puhul on oluline, et professionaalse arengu toetamise tegevused oleksid seotud õpetaja igapäevase tööga ning võimaldaks neil aktiivselt oma õppimist juhtida (Berliner, 2004). Samuti on kogenud õpetajatele tähtis koostöö kolleegiga, mis loob aja ja ruumi oma mõtete ja teadmiste korrastamiseks ning õpetaja tegevuse ja õpilaste õppimise vaheliste seoste märkamiseks (Gellert, 2008; Timperley, 2008). Suunatud refleksiooni protseduuris rakendatud oma tegevuse filmimine aitab kogenud õpetajal siduda professionaalse arengu toetamise tegevused otseselt oma igapäevase praktikaga. Lisaks toetab tähenduslike olukordade valimine vastutuse võtmist iseenda ja õpilaste arengu juhtimise eest. Niisamuti hindasid õpetajad kõrgelt võimalust kaasata reflekteerimisprotsessi kolleeg. Kuigi uurijad rõhutavad, et koostöö kolleegiga on efektiivse järjepideva professionaalse arengu toetamise üks olulisi komponente (Simons \& Ruijters, 2004), on õpetajatel vähe võimalusi eesmärgipäraseks ja sisuliseks kollegiaalseks koostööks professionaalse arengu toetamise tegevuste kontekstis (European Commission, 2015), mistõttu on siinsed tulemused tähelepanuväärsed. Kokkuvõttes võib öelda, et uurimuse tulemused viitavad suunatud refleksiooni protseduuri rakendamise kasulikkusele professionaalse arengu eri etappidel olevatele õpetajatele. 
Kui ühelt poolt viitab osalejate tagasiside, et suunatud refleksiooni protseduuri rakendamine toetab neid nende professionaalse arengu etapil, siis teiselt poolt annavad tulemused alust järeldada, et see soodustab õpetajate arengut laiemalt. Nimelt näitab üliõpilaste tagasiside, et protseduuri läbitegemine aitas neil enam märgata ja teadvustada õppijatega seotud aspekte. Sealjuures on viimati nimetatud aspektid iseloomulikud pigem kogenud õpetajatele ning algaja õpetaja tähelepanu on esialgu iseendal ja oma ainealastel teadmistel (Berliner, 2004). Samal ajal aga tõid kogenud õpetajad välja, et refleksiooniprotseduuri läbitegemine aitas neil iseennast õpetajana paremini tundma õppida. Sealjuures rõhutasid kogenud õpetajad võimalust märgata enda tugevusi ja olukordi, mis õnnestusid. Kogenud õpetajatele on iseloomulik, et nad keskenduvad peamiselt õpilaste õppimise toetamisele ning mõtestavad valdavalt neid olukordi, mis ei lähe plaanipäraselt (Berliner, 2004). Seega aitas suunatud refleksiooni protseduur kogenud õpetajatel astuda justkui sammuke tagasi ja keskenduda iseendale ja teadvustada oma tugevusi, mis oli õpetajate hinnangul jõustav.

Siinse uurimuse tulemused viitavad ka suurele kitsaskohale õpetaja professionaalse arengu toetamises. Nimelt on murekohaks õpetajate väljendatud ebakindlus enda kui professionaali ühe olulise tunnuse suhtes ehk oma teoreetiliste teadmiste pideva täiendamise, praktilise kogemusega seostamise ning seeläbi oma õpetamisteooria loomise suhtes, mis aitab õpetajal langetada tõenduspõhiseid otsuseid ja annab talle ühelt poolt autoriteedi ja toob teiselt poolt kaasa autonoomsuse (Leijen et al., 2019; Pedaste, Leijen, Poom-Valickis, \& Eisenschmidt, 2019; Simons \& Ruijters, 2014). Üliõpilastele valmistas eelkõige raskusi välja valitud konkreetsete olukordade mõtestamine. Täpsemalt öeldes tundsid nad, et nende teoreetilised teadmised on liiga üldised, et neist oleks kasu niivõrd spetsiifiliste olukordade mõtestamisel.

Ka varasemad uurimused on näidanud, et õpetajakoolituse üliõpilased hindavad oma pedagoogika- ja aineteadmisi madalalt (nt Luik \& Taimalu, 2018). Need tulemused on kooskõlas Berlineri (2004) õpetaja professionaalse arengu käsitlusega. Nimelt on õpetajakoolituse üliõpilased Berlineri (2004) järgi alustava õpetaja tasemel, kelle teadmised ongi veel üldised. Selles etapis õpivad üliõpilased alles märkama, mis õpetamissituatsioonis toimub. Sel ajal ei ole nad veel valmis märkama praktika ja teooria seoseid ning vajavad selleks välist tuge. Kogenud õpetajad seevastu kahtlesid, kas nende teoreetilised teadmised on asjakohased. Nad väljendasid ebakindlust pidevalt uuenevate teadmiste suhtes. Need tulemused võivad viidata sellele, et senised viisid, kuidas uus erialane informatsioon õpetajateni jõuab, ei pruugi olla piisavalt kättesaadav. Lisaks on tähelepanuväärne, et erineva kogemusega õpetajad väljendasid teadmatust, kust ja kuidas leida asjakohast teoreetilist teadmist. Seega viitavad 
siinse uuringu tulemused ühelt poolt vajadusele toetada teadlikumalt erialase informatsiooni kättesaadavust ning teiselt poolt vajadust toetada ópetajate oskust leida teoreetilist teadmist ja seostada see oma praktilise kogemusega.

Kokkuvõttes annavad siinse uurimuse tulemused läbilõikelise ülevaate, kuidas tajuvad õpetajad professionaalse arengu eri etappidel suunatud refleksiooni protseduuri kasutegureid ja kitsaskohti. Uurimuse tulemused viitavad sellele, et protseduuri rakendamisel on professionaalse arengu eri etappidel olevate õpetajate jaoks kasutegureid, pakkudes mitmekülgseid toetusmeetmeid oma praktika mõtestamiseks ja parendamiseks, alustades videosalvestisest ja tähenduslike olukordade valimisest ning lõpetades kaaslaste toe ja suunavate küsimustega. Uurimuse tulemused osutavad sellele, et sama protseduuri aspekte on võimalik kohandada õpetajate erinevate vajaduste ja ootustega. Seega on tegemist paindliku meetodiga, mida saab võtta aluseks professionaalse arengu eri etapil olevate õpetajate toetamisel. Siinse uurimuse tulemuste tõlgendamisel tuleb aga arvesse võtta, et tegemist on õpetajate endi hinnangutega. Kahtlemata oleks väärtuslik uurida lähemalt ka õpetajate refleksioone ning suunatud refleksiooni protseduuri läbitegemise tulemusel sisse viidud muudatusi õpetajate praktikas.

\section{Tänusõnad}

Artikli autorid tänavad kõiki uurimuses osalenud õpetajaid ja üliõpilasi nende koostöövalmiduse, avatuse ja hindamatu panuse eest, mis aitab lahti mõtestada, kuidas õpetajaid paremini toetada.

Artikli kirjutamist ja uurimuste korraldamist toetas Tartu Ülikooli ASTRA projekt PER ASPERA ning finantseeris Euroopa Liidu Regionaalarengu Fond ja Euroopa Komisjon.

\section{Kasutatud kirjandus}

Allas, R., Leijen, Ä, \& Toom, A. (2017). Supporting The Construction of Teacher's Practical Knowledge Through Different Interactive Formats of Oral Reflection and Written Reflection. Scandinavian Journal of Educational Research, 61(5), 600-615. https://doi.org/10.1080/00313831.2016.1172504

Beijaard, D., Meijer, P. C., \& Verloop, N. (2004). Reconsidering research on teachers' professional identity. Teaching and Teacher Education, 20, 107-128. https://doi.org/10.1016/j.tate.2003.07.001

Berliner, D. (1988). The development of expertise in pedagogy. Charles W. Hunt Memorial Lecture presented at the Annual Meeting of the American Association of Colleges for Teacher Education (New Orleans, LA, February 17-20, 1988). 
Berliner, D. (2001). Learning about and learning from expert teachers. International Journal of Educational Research, 35, 463-482.

https://doi.org/10.1016/S0883-0355(02)00004-6

Berliner, D. (2004). Describing the Behavior and Documenting the Accomplishments of Expert Teachers. Bulletin of Science, Technology \& Society, 24, 200-212. https://doi.org/10.1177/0270467604265535

Billing, D. (2007). Teaching for transfer of core/key skills in higher education: Cognitive skills. Higher Education, 53, 483-516. https://doi.org/10.1007/s10734-005-5628-5

Borko, H., Jacobs, J., \& Koellner, K. (2010). Contemporary Approaches to Teacher Professional Development. In P. Peterson, E. Baker, and B. McGraw (Eds.), International Encyclopaedia of Education (3 ${ }^{\text {rd }}$ ed., pp. 548-556). Oxford: Elsevier. https://doi.org/10.1016/B978-0-08-044894-7.00654-0

Brenammar, K. (2004). Conscious Action Through Conscious Thinking - Reflection Tools in Experiential Learning. Public seminar. Amsterdam: Amsterdam University Press.

Caena, F. (2011). Literature review. Teachers' core competences: requirements and development. European Commission.

Cochran-Smith, M. C. (2003). Learning and Unlearning: The Education of Teacher Educators. Teaching and Teacher Education, 19(1), 5-28. https://doi.org/10.1016/S0742-051X(02)00091-4

Darling-Hammond, L., Chung Wei, R., Alethea, A., Richardson, N., \& Orphanos, S. (2009). Professional Learning in The Learning Profession: A Status Report on Teacher Development in The United States and Abroad. Stanford, CA: National Staff Development Council and The School Redesign Network.

Denzin, N. K. (1978). The Research Act: A Theoretical Introduction to Sociological Methods. New York: McGraw-Hill.

Desimone, L. M. (2009). Improving Impact Studies of Teachers' Professional Development: Toward Better Conceptualizations and Measures. Educational Researcher, 38(3), 181-199. https://doi.org/10.3102/0013189X08331140

Dewey, J. (1933). How we think. Buffalo, NY: Prometheus Books.

European Commission (2015). Shaping career-long perspectives on teaching. A guide on policies to improve Initial Teacher Education. Brussels: European Commission.

Evans, L. (2002). What is teacher development? Oxford Review of Education, 28(1), 123-137. https://doi.org/10.1080/03054980120113670

Feiman-Nemser, S. (2001). From Preparation to Practice: Designing A Continuum to Strengthen and Sustain Teaching. Teachers College Record, 103(6),1013-1055. https://doi.org/10.1111/0161-4681.00141

Fuller, F. F. (1969). Concerns of teachers: A developmental conceptualization. American Education Research Journal, 6, 207-226. https://doi.org/10.3102/00028312006002207

Gellert, U. (2008). Routines and Collective Orientations in Mathematics Teachers' Professional Development. Educational Studies in Mathematics, 67(2), 93-110. https://doi.org/10.1007/s10649-007-9089-x

Husu, J., Toom, A., \& Patrikainen, S. (2008). Guided reflection as a means to demonstrate and develop student teachers reflective competencies. Reflective Practice, 9(1), 37-51. https://doi.org/10.1080/14623940701816642 
Kelchtermans, G. (2004). CPD for professional renewal: moving beyond knowledge for practice. In C. Day \& J. Sachs (Eds.), International Handbook on the Continuing Professional Development of Teachers (pp. 217-237). Maidenhead: Open University Press.

Knezic, D., Meijer, P., Toom, A., Leijen, Ä., Mena, J., \& Husu, J. (2019). Student teachers' self-dialogues, peer dialogues, and supervisory dialogues in placement learning. European Journal of Teacher Education, 42(5), 539-556. https://doi.org/10.1080/02619768.2019.1652901

Korthagen, F. A. J. (2004). In search of the essence of a good teacher: Towards a more holistic approach in teacher education. Teaching and Teacher Education, 20, 77-97. https://doi.org/10.1016/j.tate.2003.10.002

Korthagen, F. A. J., \& Vasalos, A. (2005). Levels in reflection: Core reflection as a means to enhance professional growth. Teachers and Teaching: Theory and Practice, 11(1), 47-71. https://doi.org/10.1080/1354060042000337093

Kõrgesaar, J. (2018). Terviklik teooria psüühika ja selle arengu kohta. Eesti Haridusteaduste Ajakiri, 6(1), 220-230. https://doi.org/10.12697/eha.2018.6.1.10

Leijen, Ä., Lam, I., Wildschut, L., \& Simons, P. R. J. (2009). Difficulties teachers report about students' reflection: Lessons learned from dance education. Teaching in Higher Education. 14(3), 315-326. https://doi.org/10.1080/13562510902898882

Leijen, Ä., Pedaste, M., \& Lepp, L. (2019). Teacher agency following the ecological model: How it is achieved and how it could be strengthened by different types of reflection. British Journal of Educational Studies, 1-16. https://doi.org/10.1080/00071005.2019.1672855

Leijen, Ä., Valtna, K., Leijen, D. A. J., \& Pedaste, M. (2012). How to determine the quality of students' reflections? Studies in Higher Education, 37(2), 203-217. https://doi.org/10.1080/03075079.2010.504814

Luik, P., \& Taimalu, M. (2018). Lasteaiaõpetajate ja koolieelse lasteasutuse õpetajaks õppivate üliõpilaste hinnangud oma aine-, pedagoogika- ja tehnoloogiateadmistele ning nende teadmiste integreerimisele. Eesti Haridusteaduste Ajakiri, 6(1), 136-156. https://doi.org/10.12697/eha.2018.6.1.06

Meijer, P. C., de Graaf, G., \& Meirink, J. (2011). Key experiences in student teachers' development. Teachers and Teaching: theory and practice, 17(1), 115-129. https://doi.org/10.1080/13540602.2011.538502

Meijer, P. C., Zanting, A., \& Verloop, N. (2002). How can student teachers elicit experienced teachers' practical knowledge? Tools, suggestions, and significance. Journal of Teacher Education, 53(5), 406-419. https://doi.org/10.1177/002248702237395

Moon, J. A. (2004). Reflection in learning and professional development. New York: Routledge-Falmer.

OECD (2009). Education at a Glance 2009: OECD Indicators. OECD Publishing: Paris. OECD (2015). Education at a Glance 2015: OECD Indicators. OECD Publishing: Paris. OECD (2019), TALIS 2018 Results (Volume I): Teachers and School Leaders as Lifelong Learners. TALIS, OECD Publishing: Paris.

Okas, A., van der Schaaf, M., \& Krull, E. (2016). Õpetajate tegevus tunnis: õpilaste hinnangud ja nende kooskõla õpetajate arusaamisega. Eesti Haridusteaduste Ajakiri, 4(1), 195-222. https://doi.org/10.12697/eha.2016.4.1.07 
Patton, M. (1990). Qualitative evaluation and research methods (pp. 169-186). Beverly Hills, CA: Sage.

Pedaste, M., Leijen, Ä., Poom-Valickis, K., \& Eisenschmidt, E. (2019). Teacher professional standards to support teacher quality and learning in Estonia. European Journal of Education, 54(3), 389-399. https://doi.org/10.1111/ejed.12346

Procee, H. (2006). Reflection in education: A Kantian epistemology. Educational Theory, 56(3), 237-362. https://doi.org/10.1111/j.1741-5446.2006.00225.x

Rodgers, C. R. (2002). Defining Reflection: Another Look at John Dewey and Reflective Thinking. Teachers College Record, 104(4), 842-866. https://doi.org/10.1111/1467-9620.00181

Ryan, G. W., \& Bernard, H. R. (2003). Techniques to Identify Themes. Fields Methods, 15(1), 85-109. https://doi.org/10.1177/1525822X02239569

Schön, D. (1983). The reflective practitioner: How professionals think in action. New York: Basic Books.

Shulman, L. S., \& Shulman, J. H. (2004). How and What Teachers Learn: A Shifting Perspective. Journal of Curriculum Studies, 36(2), 257-271. https://doi.org/10.1080/0022027032000148298

Simons, P. R.-J., \& Ruijters, M. C. P. (2014). The Real Professional Is a Learning Professional. S. Billett, C. Harteis, and H. Gruber (Eds.), International Handbook of Research in Professional and Practice-based Learning (pp. 955-985). Springer International Handbooks of Education: Springer, Dordrecht. https://doi.org/10.1007/978-94-017-8902-8_35

Sööt, A., \& Leijen, Ä. (2012). Designing support for reflection activities in tertiary dance education. Procedia - Social and Behavioral Sciences, 45, 448-456. https://doi.org/10.1016/j.sbspro.2012.06.581

Zhang, M., Lundeberg, M., Koehler, M. J., \& Eberhardt, J. (2011). Understanding Affordances and Challenges of Three Types of Video for Teacher Professional Development. Teaching and Teacher Education, 27(2), 454-462. https://doi.org/10.1016/j.tate.2010.09.015

Timoštšuk, I., Ugaste, A., \& Mets-Alunurm, K. (2018). Õpetajate õppimiskogemused neoliberaalsete haridusmuutuste taustal. Eesti Haridusteaduste Ajakiri, 6(1), 77-101. https://doi.org/10.12697/eha.2018.6.1.04

Timperley, H. (2008). Teacher Professional Learning and Development. Paris: UNESCO.

Toom, A., Tiilikainen, M., Heikonen, L., Leijen, Ä., Mena, J. \& Husu, J. (2019). Teacher candidate learning of action-oriented knowledge from triggering incidents in teaching practice. Teachers and Teaching. 1-17.

https://doi.org/10.1080/13540602.2019.1652162

Toomela, A. (2015). Arengust, õppimisest, õpetamisest ja pääsukestest. E. Kikas \& A. Toomela (Eds.). Õppimine ja õpetamine kolmandas kooliastmes. Üldpädevused ja nende arendamine (pp. 15-33). Tallinn: Eesti Ülikoolide Kirjastus OÜ.

Tripp, D. (1993). Critical incidents in teaching: Developing professional judgement. London: Routledge. 


\title{
The main benefits and challenges of implementing a guided reflection procedure as perceived by student teachers and teachers
}

\author{
Raili Allas ${ }^{a 1}$, Äli Leijen ${ }^{a}$, Auli Toom ${ }^{\mathrm{b}}$ \\ ${ }^{a}$ Institute of Education, University of Tartu \\ ${ }^{b}$ Centre for University Teaching and Learning, University of Helsinki
}

\begin{abstract}
Summary
Our society is rapidly changing and this requires professionals to continually redevelop their skills, knowledge and attitudes. These ever-changing circumstances set new expectations for teachers - they are expected to help children become future professionals who are able to adapt to unexpected societal expectations (OECD, 2019). Thus, there is an increasing focus on teachers' continuous professional development and the search for evidence-based approaches to support teachers (European Commission, 2015; Feiman-Nemserv, 2001; OECD, 2019). Additionally, it must be borne in mind that the teaching staff is becoming more heterogeneous, which means that teachers in need of support are very different in terms of their preparation and hence their needs (OECD, 2019). Therefore, there is a need to find methods that could be beneficial for teachers at different stages of their professional development. Although educational researchers agree that reflection is an integral part of teacher professional development (Caena, 2011), further research is needed to find a method that is effective in supporting different teachers. This article aims to describe how teachers at different stages of their professional development perceive the benefits and disadvantages of a guided reflection procedure (Allas et al., 2017).

Development is determined as a process that results in qualitative changes in the psyche as a whole (Kõrgesaar, 2016; Toomela, 2016). In the context of supporting teachers, the terms teacher professional development and continuous professional development are emphasised. It is indicated that continuous professional development supports the teachers' ability to cope on a daily basis (OECD, 2015; Timperley, 2008), but it is not explained what kind of changes will occur during the development. Evans (2002) has defined teacher development as a process that can be internally or externally driven and that can improve the status of the teaching profession and the knowledge, skills, and
\end{abstract}

Institute of Education, University of Tartu, Salme 1a, Tartu, 50103 Estonia; raili.allas@ut.ee 
practices of teachers. She distinguishes between two fundamental components of teacher development that express the focus of changes: 1) attitude-related development that changes teachers' attitudes toward work; 2) activity-related development that improves teacher's professional practice. This definition provides a framework for understanding the teacher's professional development, but there is still a need to define universally applicable features of the teacher's professional development process to describe how teachers move from one level to another.

Berliner (1988) has identified the following features in defining teacher professional development as a process: 1) classroom perception, interpretation, and prediction; 2) distinguishing significant events; 3) use of routines; 4) responsibility for one's actions. During different stages of their professional development, teachers need specific support in relation to these features. During the early stages, external support is necessary to initiate careful examination of one's own teaching, for identifying typical characteristics of teaching and acquiring the initial teaching skills (Berliner, 2004). Through constant meaning-making of their experiences, teachers acquire a better perception of the classroom, learn to interpret classroom events and to use what was learnt previously to predict and manage their future actions. Teachers begin to construct integrated knowledge systems from which knowledge is more easily retrieved. Accordingly, teachers become more flexible in their teaching as some routinisation of everyday repetitive actions occur (Berliner, 2004). Additionally, teachers learn to take more control of their own actions and more responsibilities for supporting their students' learning. During the later stages, teachers need opportunities to guide their development and ways to learn from everyday classroom practice (Borko et al., 2010). Furthermore, Simons and Ruijters (2014) emphasise the importance of actively maintaining the theory of teaching and keeping it up-to-date and connecting it to classroom practice that in turn contributes to teacher authority and autonomy.

Previous studies make clear that giving meaning to one's own practical experiences and interpreting these in the light of existing and new knowledge is at the centre of supporting teachers at different stages of their professional development, which suggests that reflection is the most important way to support teachers. Reflection refers to the cognitive process that aims to construct knowledge based on practical experiences individually or with the support of others (Dewey, 1933; Korthagen, 2004; Schön, 1983). Therefore, carefully designed reflection assignments could be beneficial to support teachers at the different stages of their professional development.

In this study, feedback from 21 student teachers and 80 teachers were collected and analysed to describe how teachers at different stages of their 
professional development perceive the benefits and disadvantages of the guided reflection procedure (Allas et al., 2017). All participants carried out the procedure that consisted of four stages: 1) filming one's own teaching, 2) selecting two meaningful events (one empowering, one challenging), 3) carrying out oral reflection on the selected events; and 4) writing a reflection on the selected and discussed events. Semi-structured group interviews and group discussions were implemented to collect participants' feedback and thematic content analysis (Ryan \& Bernard, 2003) was used to evaluate the data, and investigator triangulation was carried out to ensure the trustworthiness of the data interpretation (Denzin, 1978).

The results of the study suggest that, in general, different teachers found the procedure to be beneficial. This result is important because one of the concerns related to enhancing teachers' continuous professional development is that teachers do not perceive the methods offered to support their everyday practice as useful (Borko et al., 2010; OECD, 2009). If teachers perceive the supportive methods as potentially beneficial for enhancing their everyday teaching, they are more motivated to contribute to these activities.

Additionally, the results indicate that the guided reflection procedure enabled teachers with varying degrees of experience, expectations and needs, to utilise the different supportive aspects that were integrated into the procedure to enhance reflection. More precisely, teachers with less experience were able to use the video recording of their own teaching, the guiding questions and external support from a peer or supervisor to identify the typical characteristics of teaching, to become accustomed to interpret the situations from different perspectives and to learn from their experiences to use the constructed knowledge to guide their future actions (Berliner, 2004). At the same time, the teaching video and the opportunity to select meaningful events allowed experienced teachers to take the initiative in designing their own development, to base learning on their everyday setting and to focus on student learning. Similarly, the opportunity to carry out an oral reflection with a colleague enabled them to organise their thoughts and knowledge and to notice the relationship between their activities and student learning (Gellert, 2008; Timperley, 2008).

Moreover, the results indicate that the procedure guided teachers to move beyond what was expected from them at their professional development stage. More specifically, the guided reflection procedure broadened less experienced teachers' focus and encouraged them to notice aspects related to students and their learning that is more common to experienced teachers (Fuller, 1969). At the same time, the procedure directed experienced teachers to take a closer look at themselves as teachers, at their strengths, and to recognise the aspects that they succeed in which is less common as experienced teachers appear 
to be reflective mainly when something is not proceeding according to plan (Berliner, 2004).

Furthermore, the results highlight an important concern related to supporting teachers at the different stages of their professional development. More precisely, teachers with different experiences expressed difficulties with integrating their theoretical knowledge with their practical experiences. Novice teachers stated that they had insufficient theoretical knowledge in order to give meaning to their specific meaningful events. Experienced teachers, on the other hand, were concerned about the relevance of their theoretical knowledge since the field of educational theory expands rapidly. Moreover, teachers at different stages of their development expressed uncertainty regarding finding new theoretical knowledge. This result is remarkable as it is an important characteristic of a professional to constantly renew one's body of theory to be able to take evidence-based decisions (Leijen et al., 2019; Pedaste et al., 2019; Simons \& Ruijters, 2014).

In conclusion, the results of this study suggest that teachers at different stages of their professional development perceive the guided reflection procedure as useful. At the same time, the study reveals the need to support teachers in connecting their theoretical knowledge to their practical experiences.

Keywords: guided reflection procedure, teacher's professional development, reflection 